\title{
Performance of interspecific grapevine varieties in north-east Italy
}

\author{
Pacifico Daniela $^{1^{*}}$, Gaiotti Federica ${ }^{2}$, Giusti Mirella ${ }^{2}$, Tomasi Diego ${ }^{2}$ \\ ${ }^{1}$ Agricultural Research Council-Research Centre for Industrial Crops, Bologna, Italy; \\ *Corresponding Author: daniela.pacifico@entecra.it \\ ${ }^{2}$ Agricultural Research Council-Viticulture Research Centre, Conegliano, Italy
}

Received 3 January 2013; revised 3 February 2013; accepted 10 February 2013

\begin{abstract}
A renewed interest in inter-specific varieties has recently emerged, due mainly to producers and consumers more aware of organic farming and impact of phytochemicals in the environment. The assessment of 19 European Vitis hybrids was investigated in an area mostly dedicated to viticulture, the North-Eastern Italy. Major agronomic traits, yield, quality characteristics and disease resistance were evaluated during a three-year period (2004 to 2006). Wine sensory analyses were performed and compared with international Vitis vinifera varieties. Even though no genotypes resulted adequate for market release, the results obtained confirm the potential importance of hybrids in an "eco-friendly" viticulture and identify the genotypes interesting for further investigation and breeding: GF 138-3 and GA 48-12 showed good agronomic performance, resistance to more grape diseases and high quality wine.
\end{abstract}

Keywords: Hybrids; Organic Viticulture; Yield; Quality; Disease Resistance

\section{INTRODUCTION}

Successful viticulture must meet the requests of consumers and growers for good wine quality, disease and insect tolerance and low environmental impact $[1,2]$. Recurrent environmental issues have increasingly sparked political-social discussions over the last ten years. The European agricultural policies implemented guidelines focused on improved management strategies, integrated agronomic practices in the vineyard (2009/128/CE Directive) and a reduction in the use of pesticides and fungicides, using more disease-tolerant varieties in place of conventional ones. Hybrid varieties could be the most promising tool for low input, low cost and time-saving viticulture because of their tolerance to diseases and insects $[3,4]$. The wine industries in many extra-European Union countries currently use a high percentage of inter-specific varieties with good results and fund specific breeding programmes [5]. In Canada, USA, Switzerland, Germany and Hungary several inter-specific wines are commercialised.

Since 1960, inter-specific varieties had been used to successfully introgress tolerance to pests and diseases, such as powdery mildew (Erysphe necator Schwein), downy mildew (Plasmopara viticola) or phylloxera (Dactulosphaira vitifoliae Ficth.) [6-8]. These varieties are the result of efforts to combine the quality of traditional European varieties (Vitis vinifera) and pyramid different resistance traits typical of American varieties (Vitis riparia, Vitis labrusca, Vitis aestivalis, Vitis berlandieri and Vitis amurensis). Inter-specific breeding was especially important after the massive destruction of European vineyards, as consequence of the invasion of serious fungal diseases from the US during the second half of the $19^{\text {th }}$ Century. At the beginning of $20^{\text {th }}$ century, over 6000 hybrids were registered in Europe. Unfortunately, the offspring of these varieties often lose the stable yield and good quality traits of their European parents due to the complex polygenic base, which governs the resistance and the quality of the grapes $[9,10]$, demonstrating that inter-specific breeding methods are quite unsuccessful. Finally, the diffusion of pesticides, the employment of the first rootstocks tolerant to phylloxera, the low quality of wines obtained and the possible presence of toxic metabolites have led to the unpopularity of hybrids $[11,12]$. Since then, crosses have been only performed in Germany [7,13], Austria [14], France [15] and Hungary [16]. In 1990, European wine area cultivated with hybrids was greatly reduced $[0.04 \%$, especially concentrated in Romania; 17]. Anyway, for many years, the Experimental Station for Viticulture (now CRA-VIT) in Conegliano (Treviso, Italy) investigated the quality of second-generation inter-specific hybrids $[18,19]$. In 1986, the first attempts to use in vitro plantlets to screen grape 
genotypes for resistance to disease infections were reported [20]. More recently, marker-assisted selection (MAS) has been use to greatly improve the introduction of genetic complex traits, such as grape quality and disease resistance, through reduced time and costs and avoiding the many problems that typically result from backcrosses [21-25].

Currently, the promising market of hybrids was first established through the cultivation of "Regent" in Germany, where it is grown over an area of more than 600 ha; a future similar trend in Europe, particularly in Italy (INFOAM 2000; Deutsches Weinbaujahrbuch 19952003), can be foreseen. As soil, location and climate (typically referred together as Terroir) play a central role in vine performance and wine qualitative characteristics, the relationship between the hybrids and the environment is a crucial aspect that must be considered to evaluate their potential adoption in the investigated area. Thus, the aim of this study was to survey phenological, agronomic and qualitative performances, along with their resistance to the most common vine diseases, of 19 European wine grape hybrids.

\section{MATERIALS AND METHODS}

\subsection{Site and Genotypes Description}

The 19 inter-specific red and white wine grapes varieties, listed in Table $\mathbf{1}$ and present in the field collection of the CRA-VIT (Research Centre for Viticulture) in Conegliano (Treviso, Italy $45^{\circ} 51^{\prime} 8.92^{\prime \prime} \mathrm{N}, 12^{\circ} 15^{\prime} 31.53^{\prime \prime} \mathrm{E}$ ) were replanted in an experimental vineyard located near Motta di Livenza (Treviso, Italy $45^{\circ} 47^{\prime} 5.91^{\prime \prime} \mathrm{N}$, $\left.12^{\circ} 35^{\prime} 38.90 " \mathrm{E}\right)$.

The hybrids were monitored for 3 years (2004 to 2006) and compared for agronomic parameters and disease resistance with "Pinot gris", as this is an international cultivar widely cultivated in the area. The site is characterrised by a heavy soil (35\% - 40\% of clay). The climatic data accumulated for 3 years of study, are reported in Table 2. Approximately 11 - 13 chemical treatments per year against powdery and downy mildew are usually applied because the climate and soil conditions make this site habitat particularly suitable for high-severity fungal diseases. Anyway, to assess the resistance against fungal diseases, the varieties under investigation were treated only four times during the vegetative period, using formulations without copper before flowering and with copper hydroxide after flowering. Canopy and soil management were conducted according to practices commonly adopted in the vineyards of the area. The vine spacing was $3 \times 1.7 \mathrm{~m}$ (1960 vines/ha), and the vines were trained using the Sylvoz system, with 3 canes of 10 - 12 buds each. The cultivars were grafted on the rootstock Kober 5 BB. The experimental design was replicated using three 15-plant blocks for each hybrid.

\subsection{Analysis}

The main phenological stages, such as budbreak, bloom and veraison (defined as $50 \%$ of plants upon the

Table 1. Inter-specific varieties investigated in the study: colour of berry, origin of varieties and their pedigree are reported.

\begin{tabular}{|c|c|c|c|c|}
\hline Cultivars & Sinonyms & Color of berry skin & Origin & Pedigree \\
\hline A $\times$ GM 64-94-5 & - & Black & Geisenheim (D) & Arnsburger × GM 64-94-5 (Rondo) \\
\hline Ambror & Seibel 10173 & White & France & Seibel $5455 \times$ Seibel 6089 \\
\hline GA $48-12$ & Geilweilerhof GA 48-12 & White & Geilweilerhof (D) & Bacchus $\times$ S.V. 12-375 \\
\hline GA $52-42$ & Geilweilerhof GA 52-42 & White & Geilweilerhof (D) & Bacchus $\times$ Villard Blanc \\
\hline GF $138-3$ & - & Black & Geilweilerhof (D) & Diana $\times$ Chambourcin \\
\hline GF $64-170-1$ & Geilweilerhof 64-170-1 & White & Geilweilerhof (D) & Bacchus $\times$ Seyval \\
\hline GM 723-4 & - & White & Geisenheim (D) & Arnsburger $\times$ Seyve-Villard 52-76 \\
\hline GM 7743-8 & - & White & Geisenheim (D) & Riesling KI.239GM × GM6495-1 \\
\hline Orion & GA $58-30$ & White & Geilweilerhof (D) & Optima $\times$ S.V.12-375 \\
\hline Phoenix & GA $49-22$ & White & Geilweilerhof (D) & Bacchus $\times$ S.V. $12-375$ \\
\hline Regent & GF $67-198-3$ & Black & Geilweilerhof (D) & Diana $\times$ Chambourcin \\
\hline Seibel 5178 & - & White & France & (Rupestris X Herbemont) X Seibel 752 \\
\hline Seibel 7052 & - & Black & France & Seibel $5163 \times$ Seibel 880 \\
\hline Sirius & GA $51-27$ & White & Geilweilerhof (D) & Bacchus $\times$ S.V. $12-375$ \\
\hline Staufer & GA $54-14$ & White & Geilweilerhof (D) & Bacchus $\times$ S.V. 12-375 \\
\hline SV $12-390$ & Seyve-Villard 12390 & Black & France & Seibel $6468 \times$ Subereux (Seibel 6905) \\
\hline SV 39639 & Seyve-Villard 39639 & White & France & SV $19-228 \times$ Villard Noir (SV 18-315) \\
\hline Villard blanc & Seyve-Villard 12375 & White & France & Seibel $6468 \times$ Subereux (Seibel 6905) \\
\hline
\end{tabular}


Table 2. Average values of mean temperature $\left({ }^{\circ} \mathrm{C}\right)$ and rainfall $(\mathrm{mm})$ in the three years under investigation.

\begin{tabular}{ccccccc}
\hline \multirow{2}{*}{ Months } & \multicolumn{2}{c}{2004} & \multicolumn{2}{c}{2005} & \multicolumn{2}{c}{2006} \\
\cline { 2 - 7 } & Tm & Rainfall & Tm & Rainfall & Tm & Rainfall \\
\hline January & 4.8 & 135 & 1.8 & 52 & 4.1 & 85 \\
February & 3.7 & 53 & 5.1 & 28 & 2.3 & 34 \\
March & 10.5 & 6 & 7.1 & 30 & 6 & 6 \\
April & 11.8 & 127 & 11.4 & 26 & 12.7 & 93 \\
May & 17.2 & 51 & 16.5 & 149 & 17.5 & 110 \\
June & 20.7 & 37 & 19.1 & 160 & 21.9 & 53 \\
July & 21.4 & 31 & 24.7 & 58 & 21.3 & 62 \\
August & 16.8 & 71 & 21.4 & 93 & 21.3 & 153 \\
September & 18 & 135 & 16.6 & 217 & 15.6 & 99 \\
October & 12.6 & 68 & 14 & 4 & 12.6 & 202 \\
November & 9.8 & 49 & 6.8 & 42 & 8.8 & 105 \\
December & 4.2 & 20 & 4.6 & 168 & 2.9 & 98 \\
Jan.-Dec. & 12.6 & 783 & 12.4 & 1026 & 12.3 & 1100 \\
Apr.-Sep. & 17.7 & 452 & 18.3 & 703 & 18.4 & 570 \\
\hline
\end{tabular}

stage) were evaluated and the variation quantified using standard deviation. Sugar accumulation and acid degradation were monitored upon the initiation of veraison (data not shown) to determine the ripening level and the harvest time. The shooting percentage (shoots/buds), potential fruitfulness (bunches/shoots) and real fruitfulness (bunches/buds) were determined for all the varieties. The real fruitfulness of the first four buds of each cane was also determined in 2005. All these parameters were compared among the hybrids and to "Pinot gris". At harvest, the average cluster weight and yield per vine were determined. The grape quality was analysed by measuring the soluble solids, titratable acids and $\mathrm{pH}$ using a digital refractometer (ATAGO PR-101), a manual titrator (Digitrate Pro 500-Jencons) and a Crison $\mathrm{pH}$ metre, respectively.

Based on the agronomic and grape qualitative data, 0.3 tons of grapes from only the most promising varieties were harvested yearly and microvinified (Table 3). Single vinifications were performed with each treated grape. The winemaking process was identical for all vinification experiments. The assessment of the overall wine quality was performed using blind tasting.

Taste panelists evaluated the general organoleptic characteristics, such as aroma and flavour intensity, complexity, balance, structure and finesse.

The wines from two of the most widespread varieties cultivated in the area were used as standards for the sensory analysis. "Pinot blanc" was used as a standard for white wines, as it presents more neutral aroma than "Pinot gris", and "Franconia" was used as a standard for the red wines. Both standard wines were obtained using
Table 3. List of varieties microvinified in the three years under investigation.

\begin{tabular}{|c|c|c|c|}
\hline Genotypes & 2004 & 2005 & 2006 \\
\hline Ambror & • & • & • \\
\hline GA $48-12$ & & • & • \\
\hline GA $52-42$ & - & • & \\
\hline GF $138-3$ & - & & \\
\hline Orion & - & • & - \\
\hline Phoenix & - & - & - \\
\hline Regent & • & - & - \\
\hline Seibel 5178 & & • & - \\
\hline Seibel 7052 & • & & \\
\hline Sirius & - & • & - \\
\hline Staufer & - & & \\
\hline SV 12390 & & - & \\
\hline
\end{tabular}

grape from the experimental site and by using the same winemaking process adopted for the hybrids.

The damage caused by the most common diseases associated with North-Eastern Italy climate (Downy Mildew, Botrytis and Black Rot) was assessed at harvest in 2004 and 2005 using visual inspections and evaluating leaves and bunches separately. A total of 150 clusters and 200 leaves sampled from different parts of the grapevines for each replicate were used in the assessment. Infected leaves or bunches were ranked according to a scale: $0=$ no symptoms; $1=1 \%-10 \% ; 2=10 \%-25 \% ; 3=25 \%$ $50 \% ; 4=50 \%-75 \%$; and $5=75 \%-100 \%$ of infected leaf areas or infected berries per bunch, respectively. The data regarding disease severity were processed according to Townsend-Heuberger formula [26] to calculate the percentage of infection $(I \%)$ :

$$
I \%=(\mathrm{S}(n \times v) / z \times N) \times 100
$$

where $I \%=$ percentage of infection; $n=$ number of leaves or bunches in each class; $v=$ class value; $z=$ highest class value; $N=$ total amount of assessed leaves or bunches. The data were statistically analysed using ANOVA and Duncan's multiple range test, using the statistical package "Statistica 8.1", (StatSoft Inc., 2007). The average, standard deviation and $\mathrm{P}$ were calculated.

\section{RESULTS AND DISCUSSION}

\subsection{Phenological and Agronomic Description}

The full phenological expressions of the hybrids demonstrated their adequate adaptation to the North Italian area. The mean dates for the three years, relating to the phenological stages, compared with "Pinot gris", are reported in Figure 1. In the North-East Italian areas, 

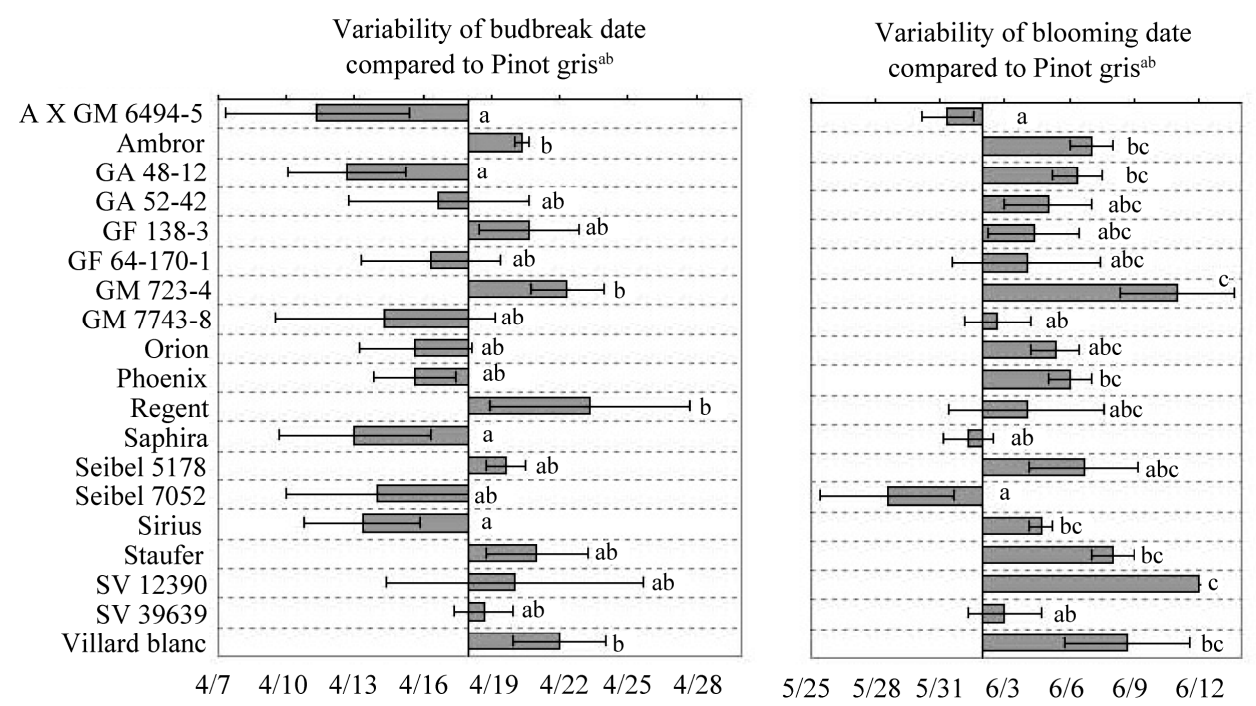

(a)
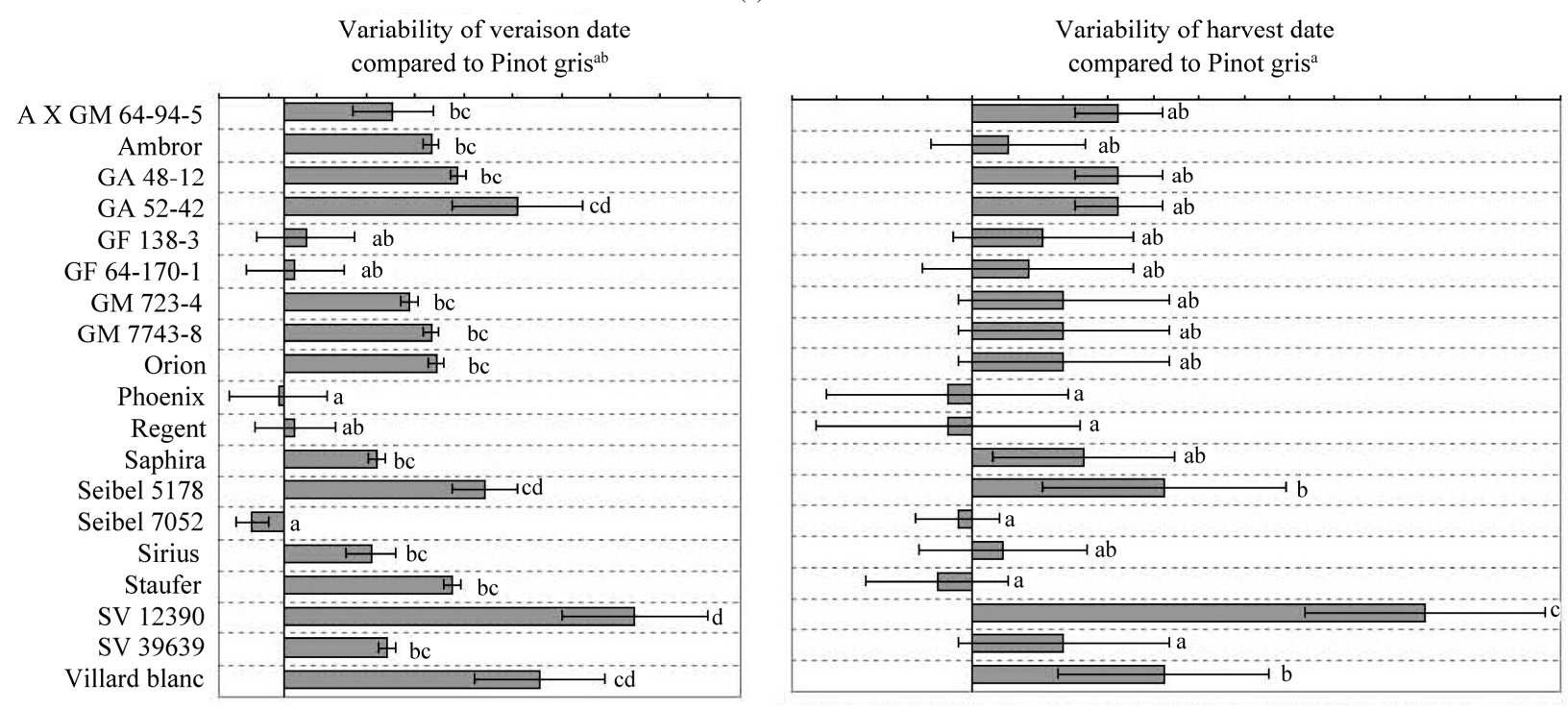

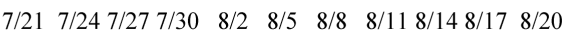

$8 / 178 / 208 / 23$ 8/26 8/29 9/1 9/4 9/7 9/10 9/13 9/16 9/19 9/22 9/25 9/28 10/1 10/4 10/7 (b)

Figure 1. Budbreak and blooming: (a) Veraison and harvest; (b) Dates (columns) of 19 hybrids compared with "Pinot gris". The data reported are average of the data registered in 2004, 2005 and 2006, and their variability was measured as standard deviations (bars). Note: letters represents the significance of variability among the varieties with $p<0.05$ (Duncan test).

"Pinot gris" is considered as an early wine grape variety, registering budbreak in the first/second decade of April, flowering in the first 10 days of June, and veraison in the last decade of July. The phenological data showed a high variability among genotypes in the budbreak phase (Figure 1(a)), reflecting a higher and different sensitivity to spring weather compared with "Pinot gris". The budding mean date of "SV 39639", "GA 52-42", "GF 64170-1", "Ambror" and "Seibel 5178" occurred in the second decade of April. "Ambror" and "Seibel 5178" were the most stable varieties observed during budbreak. The earliest cultivars were "A × GM 64-94-5", "Saphira", "GA 48-12" and "Sirius". On average, the blooming, veraison and harvest dates for these varieties all occurred later than observed with "Pinot gris". At flowering, the delay was particularly evident for "Seyve-Villard 12390" and "GM 723-4", which flowered 9 - 10 days after "Pi- not gris". Regarding the veraison date (Figure 1(b)), most varieties registered a 2-week delay compared with Pinot gris, occurring at the end of July and the beginning of August. Almost all hybrids exhibited a harvest time within the first two weeks of September (approximately 7 days after "Pinot gris"). "Staufer", "Phoenix", "Regent", and "Seibel 7052" exhibited the earliest, completing the growing season at the end of August, together with "Pinot gris", "Seyve-Villard 12390" was the only 
late variety, completing berry ripening approximately one month after "Pinot gris". Thus, this hybrid was not suitable for the investigated area, as long phenological cycles might represent a limiting factor due to autumnal frosts and rainfall that could inhibit berry maturation. The hybrids showed a longer budbreak-veraison period (107 days compared with 97 for "Pinot gris") and a quite short veraison-harvest phase (35 days compared with the 39 days observed for "Pinot gris"). The only exceptions were "Regent", which exhibited late budding and precocious harvesting, and "Seibel 7052", which was consistently precocious for all parameters tested. Shooting percentage, potential and real fruitfulness values are reported in Table 4. The shooting percentage was lower for the hybrids compared with "Pinot gris" (84.7\% vs. $92.5 \%$, respectively). In contrast, the values of fruitfulness were similar to "Pinot gris". It was evident that no fruitfulness decrease was directly associated with the use of hybrids. However, "Seibel 7052", "GM 7743-8" (Figure 2(a)) and "SV 39639" (Figure 2(b)) exhibited high fruitfulness potential, which frequently presented three bunches per shoot. Considering real and potential fruitfulness, "Seibel 7052", “GM 7743-8" and "Seyve-Villard 39639" exhib- ited better performances than the $V$. vinifera cultivar, while "Seyve-Villard 12390" and "GA 52-42" exhibited the worst performance. Alaa Al-Joumayly [27] reported that fertility coefficients are genetically determined and only slightly conditioned according to season. Notably, the fruitfulness of the first basal buds is a relevant aspect to consider the manual and mechanical spur pruning [28, 29]. "Seibel 7052", "Seyve-Villard 39639" and "GA 5242 " were unsuitable for these methods of pruning because of their low fruitfulness in the first 4 buds (Table 4). The standard deviation showed a high variation among different years, particularly for budbreak percentage.

\subsection{Grape Production and Quality}

Cluster weight $(\mathrm{g})$ and yield values ( $\mathrm{kg} / \mathrm{vine})$ of these cultivars showed an opposite trend compared with "Pinot gris", as cluster weight was, on average, lower (137 g) than that of "Pinot gris" (167 g; Table 5). "Seyve-Villard 12390" and "Villard Blanc" showed the highest cluster weight; however, "Seibel 5178", "Phoenix", "GF 138-3", "GA 52-42" and "Seyve-Villard 39639" recorded the lowest values at nearly $100 \mathrm{~g}$. The yield (tons per hectare)

Table 4. Budbrake (\%), real fruitfulness, real fruitfulness of first 4 basal buds and potential fruitfulness of the 19 hybrids compared with "Pinot gris". The data reported are average of the data registered in 2004, 2005 and 2006, and their variability was measured as standard deviations.

\begin{tabular}{|c|c|c|c|c|c|c|c|c|c|c|}
\hline \multirow{2}{*}{$\begin{array}{l}\text { Cultivars } \\
\text { Phoenix }\end{array}$} & \multicolumn{3}{|c|}{ Budbreak (\%) } & \multicolumn{3}{|c|}{ Real fertility } & \multirow{2}{*}{$\begin{array}{c}\text { Real fertility } \\
\left(1^{\circ}-4^{\circ} \text { buds }\right) \\
0.62\end{array}$} & \multicolumn{3}{|c|}{ Potential fertility } \\
\hline & 90.5 & \pm 8.3 & bc & 1.5 & \pm 0.2 & abcd & & 1.5 & \pm 0.2 & ns \\
\hline Sirius & 86.9 & \pm 4.2 & $a b c$ & 1.7 & \pm 0.2 & bcd & 0.81 & 1.6 & \pm 0.3 & ns \\
\hline Orion & 85.4 & \pm 7.7 & $a b c$ & 1.4 & \pm 0.3 & abcd & 0.97 & 2.0 & \pm 0.5 & ns \\
\hline Ambror & 86.7 & \pm 8 & abc & 1.5 & \pm 0 & abcd & 0.72 & 1.8 & \pm 0.3 & ns \\
\hline Seibel 7052 & 94.1 & \pm 4.1 & $\mathrm{c}$ & 2.2 & \pm 0.4 & $\mathrm{~cd}$ & 0.56 & 2.1 & \pm 0.6 & ns \\
\hline Seibel 5178 & 92.0 & \pm 5.3 & $\mathrm{bc}$ & 1.8 & \pm 0.2 & bcd & 0.80 & 1.6 & \pm 0.2 & ns \\
\hline GM 723-4 & 73.3 & \pm 9.3 & $\mathrm{ab}$ & 1.2 & \pm 0.2 & $\mathrm{ab}$ & 0.63 & 1.4 & \pm 0.4 & ns \\
\hline GM 7743-8 & 80.1 & \pm 5.7 & $\mathrm{abc}$ & 1.9 & \pm 0.3 & bcd & 1.10 & 1.9 & \pm 1 & ns \\
\hline Seyve Villard 12390 & 70.3 & \pm 20.9 & $\mathrm{a}$ & 0.8 & \pm 0.4 & $\mathrm{a}$ & 0.91 & 1.4 & \pm 0.2 & ns \\
\hline Seyve Villard 39639 & 94.9 & \pm 3.7 & $\mathrm{c}$ & 2.2 & \pm 0.3 & $\mathrm{~d}$ & 0.47 & 1.8 & \pm 0.8 & ns \\
\hline Villard Blanc & 82.9 & \pm 19.8 & abc & 1.2 & \pm 0.3 & $a b$ & 0.81 & 1.5 & \pm 0.2 & ns \\
\hline Staufer & 82.5 & \pm 8.6 & $\mathrm{abc}$ & 1.2 & \pm 0.6 & $a b$ & 0.55 & 1.9 & \pm 0.6 & ns \\
\hline GA 48-12 & 88.7 & \pm 6.6 & $\mathrm{abc}$ & 1.2 & \pm 0.2 & $\mathrm{ab}$ & 0.50 & 1.5 & \pm 0.3 & ns \\
\hline GA $52-42$ & 83.2 & \pm 12.4 & $\mathrm{abc}$ & 0.8 & \pm 0.3 & $\mathrm{a}$ & 0.29 & 1.3 & \pm 0.6 & ns \\
\hline Saphira & 84.7 & \pm 10.6 & $a b c$ & 1.4 & \pm 0.4 & $\mathrm{ab}$ & 1.03 & 1.7 & \pm 0.3 & ns \\
\hline $\mathrm{A} \times \mathrm{GM} 64-94-5$ & 83.0 & \pm 10.3 & $\mathrm{abc}$ & 1.8 & \pm 0.9 & bcd & 0.86 & 2.2 & \pm 0.7 & ns \\
\hline GF 64-170-1 & 84.3 & \pm 9.2 & $a b c$ & 1.3 & \pm 0.4 & $\mathrm{ab}$ & 1.22 & 1.7 & \pm 0.3 & $\mathrm{~ns}$ \\
\hline Regent & 84.6 & \pm 12.6 & $a b c$ & 1.5 & \pm 0.7 & abcd & 0.77 & 1.6 & \pm 0.6 & ns \\
\hline GF 138-3 & 81.3 & \pm 10.0 & $\mathrm{abc}$ & 1.4 & \pm 0.2 & $a b c$ & 0.68 & 1.7 & \pm 0.2 & ns \\
\hline Average & 84.7 & & & 1.3 & & & 0.8 & 1.6 & & \\
\hline Pinot gris & 92.5 & \pm 2.2 & bc & 1.4 & \pm 0.1 & abcd & 1.10 & 1.7 & \pm 0.1 & \\
\hline
\end{tabular}

Note: Letters represents the significance of variability among the hybrids with $\mathrm{p}<0.05$ (Duncan test). 
Table 5. Cluster weight and yield per vine of the 19 hybrids and "Pinot gris". The data reported are average of the data registered in the three years, and their variability was measured as standard deviations.

\begin{tabular}{|c|c|c|c|c|c|c|}
\hline \multirow{2}{*}{$\frac{\text { Cultivars }}{\text { Phoenix }}$} & \multicolumn{3}{|c|}{ Cluster weight (g) } & \multicolumn{3}{|c|}{ Yield (Kg/Vine) } \\
\hline & 104 & \pm 7 & $\mathrm{a}$ & 6.2 & \pm 0.6 & abcd \\
\hline Sirius & 159 & \pm 47 & $a b c$ & 12.1 & \pm 4.8 & $\mathrm{e}$ \\
\hline Orion & 140 & \pm 37 & $a b$ & 10.2 & \pm 1.6 & $\mathrm{~cd}$ \\
\hline Ambror & 141 & \pm 54 & $a b$ & 6.8 & \pm 1.9 & abcde \\
\hline Seibel 7052 & 131 & \pm 18 & $a b$ & 10.9 & \pm 2.3 & cde \\
\hline Seibel 5178 & 104 & \pm 14 & $\mathrm{a}$ & 5.6 & \pm 1.2 & $a b c$ \\
\hline GM 723-4 & 151 & \pm 9 & $a b$ & 8.0 & \pm 2.6 & abcde \\
\hline GM 7743-8 & 124 & \pm 28 & $a b$ & 9.8 & \pm 0.9 & bcde \\
\hline Seyve Villard 12390 & 217 & \pm 47 & $\mathrm{c}$ & 8.5 & \pm 4.7 & abcde \\
\hline Seyve Villard 39639 & 103 & \pm 23 & $\mathrm{a}$ & 7.9 & \pm 1.6 & abcde \\
\hline Villard Blanc & 181 & \pm 47 & $\mathrm{bc}$ & 7.8 & \pm 2.9 & abcde \\
\hline Staufer & 124 & \pm 21 & $a b$ & 6.8 & \pm 3.9 & abcde \\
\hline GA 48-12 & 167 & \pm 39 & $a b c$ & 9.9 & \pm 2.2 & cde \\
\hline GA 52-42 & 111 & \pm 6 & $\mathrm{a}$ & 4.1 & \pm 0.4 & $\mathrm{a}$ \\
\hline Saphira & 119 & \pm 13 & $a b$ & 4.2 & \pm 1.5 & $a b$ \\
\hline $\mathrm{A} \times \mathrm{GM} 64-94-5$ & 134 & \pm 35 & $a b$ & 8.7 & \pm 5.1 & abcde \\
\hline GF $64-170-1$ & 129 & \pm 9 & $a b$ & 7.0 & \pm 2.5 & abcde \\
\hline Regent & 161 & \pm 67 & $a b c$ & 11.7 & \pm 4.8 & de \\
\hline GF 138-3 & 110 & \pm 13 & $\mathrm{a}$ & 7.1 & \pm 1.7 & abcde \\
\hline Average & 137 & & & 8.1 & & \\
\hline Pinot gris & 167 & \pm 23 & $a b c$ & 7.3 & \pm 1.1 & abcde \\
\hline
\end{tabular}

Note: Letters represents the significance of variability among the hybrids with $\mathrm{p}<0.05$ (Duncan test).

was significantly high, with over $20 \mathrm{t} / \mathrm{h}$ obtained for the most productive hybrids and $4-5 \mathrm{t} / \mathrm{ha}$ obtained for the least productive varieties. On average, the hybrids produced more ( $8.1 \mathrm{~kg} / \mathrm{vine})$ than "Pinot gris" (7.3 kg/vine), suggesting fruitfulness, as reported by previous studies [30,31]. The most productive varieties were "Sirius", "Regent", "Seibel 7052", "Orion", "GA 48-12" and "GM $7743-8$ ", all presenting a yield greater $9 \mathrm{Kg} /$ vine. Overall, we observed high variability among the different genotypes. Over the three-year period, the "Regent" and "Ambror" registered the highest variation. The soluble solids, titratable acids and $\mathrm{pH}$ values were measured to assess the grape quality [32]. A high variability was observed among the hybrids (Figure 3), which reflect differences in their genotypes and the annual climate conditions, consistent with the observations of Pavloušek and Kumšta [33], showing the strong effect of the year and cultivar on the $\mathrm{pH}$ values and titratable acid contents. "Ambror" showed the highest soluble solid values $\left(20.1^{\circ}\right.$ Brix), followed by "Regent", "Seibel 7052" and "GF 1383", which all exhibited values superior to "Pinot gris", "Seibel 5178" and "Saphira" were similar to "Pinot gris"

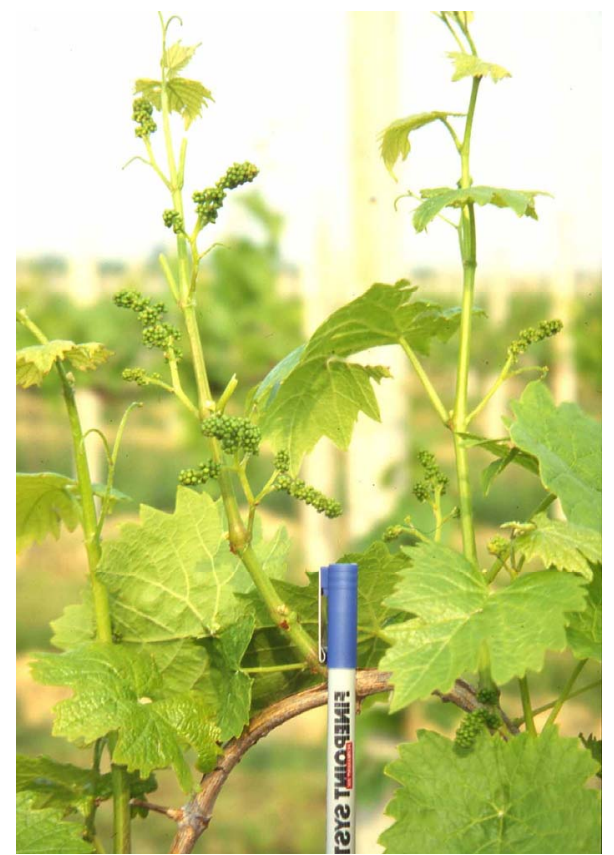

(a)

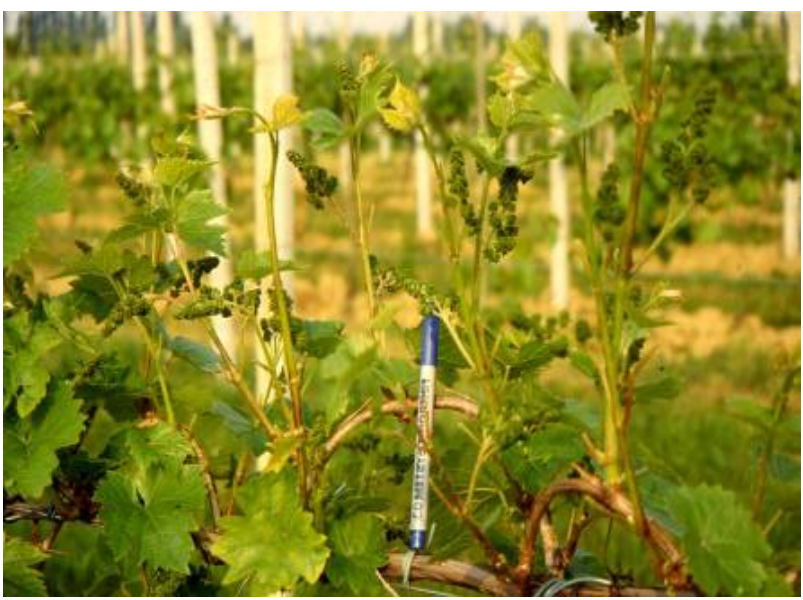

(b)

Figure 2. "GM 7743-8" (a) and "SV 39639" (b) hybrids. Note the high fruitfulness.

(18.1 $1^{\circ}$ Brix), while "Staufer" recorded the lowest value (14.8 Brix). A comparison of the yield per vine (Table 5) to the sugar richness (Figure 3) revealed that "Regent" and "Seibel 7052" had good production and high-soluble solids; no negative regression was observed among the hybrids between the two parameters. The estimated titratable acids values were primarily high for most hybrids (Figure 3(b)), which also reflected moderately low pH values (Figure 3(c)). "Seibel 7052", "Phoenix", "Sirius" and "GF 138-3" exhibited acids levels similar to "Pinot gris" (6- $7 \mathrm{~g} / \mathrm{L})$. High acid values indicate a positive trait in the present global warming scenario and also represent desirable characteristics, particularly for sparkling wines. The increase of air temperature corre- 


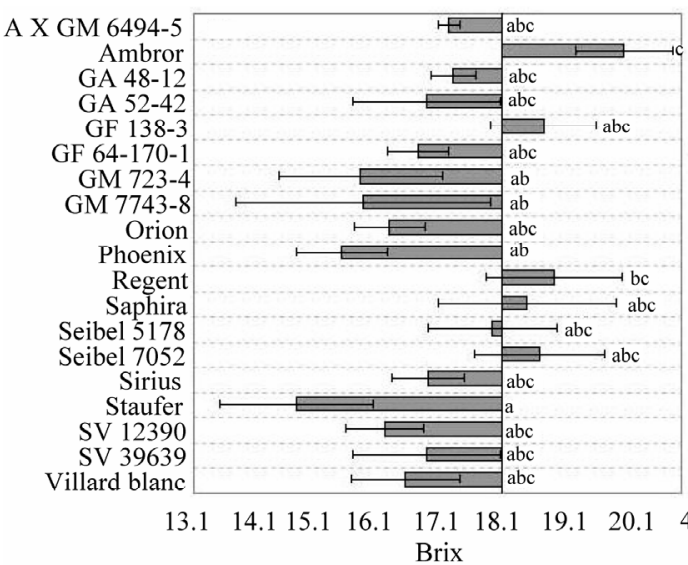

(a)
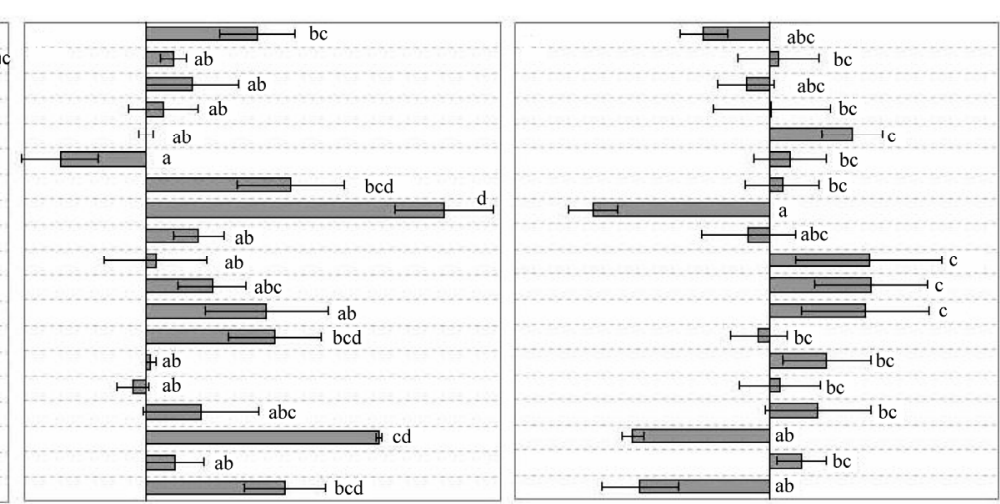

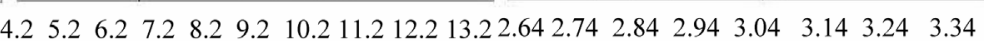
$\mathrm{g} / \mathrm{L}$

(b)
$\mathrm{pH}$

(c)

Figure 3. Soluble solids (Brix, in (a)), titratable acid (g/L, in (b)) and $\mathrm{pH}$ (in (c)) of the hybrids at harvest compared with "Pinot gris". In (a) "Pinot gris" was 18.10 Brix, in (b) $6.70 \mathrm{~g} / 1$ and in (c) 3.04. The columns show the means of the data measured during the three years and the bars indicate their variability measured as standard deviations. Note: letters indicate the significance of variability among the varieties with $\mathrm{p} \leq 0.05$ (Duncan test). "Pinot gris" showed "abc" for soluble solids, "ab" for titratable acidity and "bc" for $\mathrm{pH}$.

sponded with a similar increase in $\mathrm{pH}$ values in must. As Keller [34] suggested, the $\mathrm{pH}$ values of musts should not exceed 3.6 to avoid a decrease of quality of wine produced. As shown in Figure 3(c), all hybrids presented $\mathrm{pH}$ values below this limit.

Regarding the wine characteristics and quality, in 2004 no white wines obtained from these hybrids performed as well as the reference commercial variety ("Pinot blanc"; Figure 4(a)). The quality of "Phoenix", "GA 52-42" and "Ambror" were among the best reported, mostly for the olfactory intensity with a pronounced aroma and an adequate complexity. These qualities indicated low finesse, which is a characteristic that was confirmed in the 2005 and 2006 tastings (Figures 4(c) and (e)). Overall, "GA 48-12" demonstrated the best performance (not included in the 2004 tasting), exhibiting scores similar to "Pinot blanc". Among the remaining white varieties, "Ambror" achieved interesting results, particularly for olfactory intensity and taste persistence.

Concerning red wines obtained from hybrids, the quality was lower than the reference variety wine ("Franconia") in all three years (Figures 4(b), (d) and (f)). In 2004 (Figure 4(b)), the black wines did not exhibit high parameters associated with the bouquet or taste, except for "GF138-3", which showed appreciated values for the olfactory aromatic intensity. "Regent" exhibited increased values from the first to the third year. In 2006 (Figure $\mathbf{4 ( f )})$, the lowest yield ( $8.1 \mathrm{Kg} / \mathrm{vine})$ and sensory characteristics for "Regent" were similar to "Franconia", but the olfactory value was low.

\subsection{Estimation of Disease Tolerance}

The percentage of Downy Mildew, Botrytis and Black rot infection is reported in Table 6. During 2004 the rainfall and temperatures were standard for the area; hence, the antifungal treatments sufficiently limited disease damage. In 2005, high rainfall occurred during the blooming and berry-set periods, when the vines are more susceptible to Downey Mildew infections, and at the beginning of September, when more severe Botrytis infections occur. In the second year of the trial, "Saphira" and "Seibel 7052" were more susceptible to Downy Mildew than "Pinot gris", while "SV 39639", "SV 12390" and "Villard Blanc" were the most tolerant for leaf and cluster, exhibiting negligible symptoms of infection (Table 6). However, "Villard Blanc" showed the worst results for black rot, and "Phoenix" exhibited the highest percentage of infection for Botrytis (Table 6). Although each of the hybrids showed a high resistance to at least one of the diseases evaluated, it was not possible to identify a hybrid with a low percentage of infection for all three diseases. Even though "GF 138-3" showed a low disease incidence, "SV 12-390" resulted the most tolerant among the red wine cultivars. Whilst, three white wine cultivars, "GA 48-12", "Ambror" and "Regent", resulted adequately tolerant to Downy Mildew, consistent with the data reported in Germany [35] and in Poland [3].

\section{CONCLUSIONS}

Viticulture in North-Eastern Italy is difficult due to the high incidence of Downy Mildew and Botrytis, resulting from high rainfalls and air humidity. Unlike other European countries, e.g., France and Spain, Italy needs to drastically limit the spread of fungal diseases. The necessity of a more sustainable viticulture urgently requires the identification for new vine genotypes resistant to the more common vine diseases and the production of wine according to commercial qualitative demands. Specific 


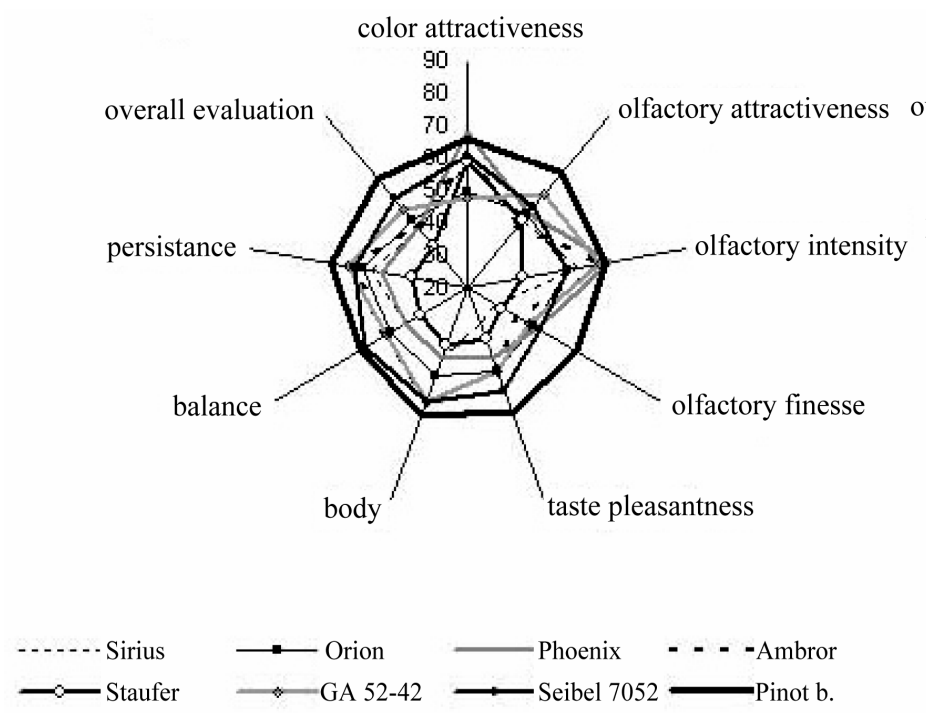

(a)
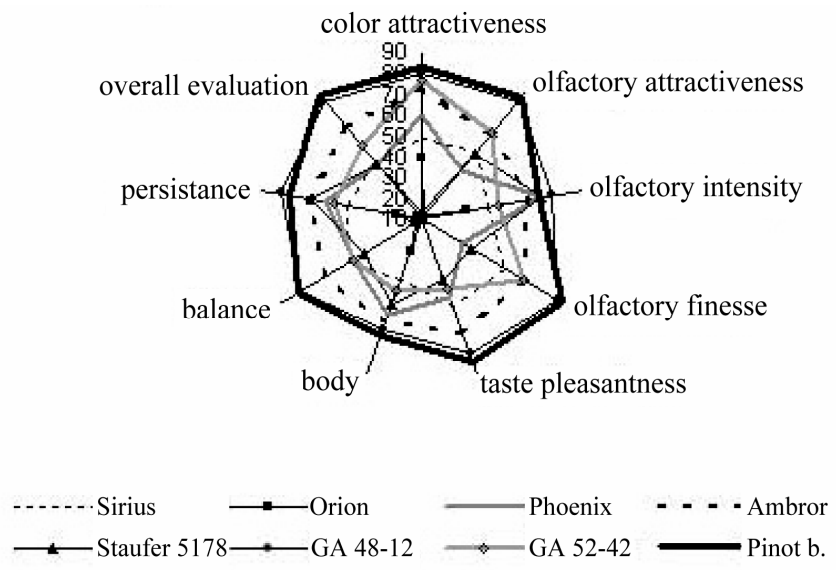

(c)

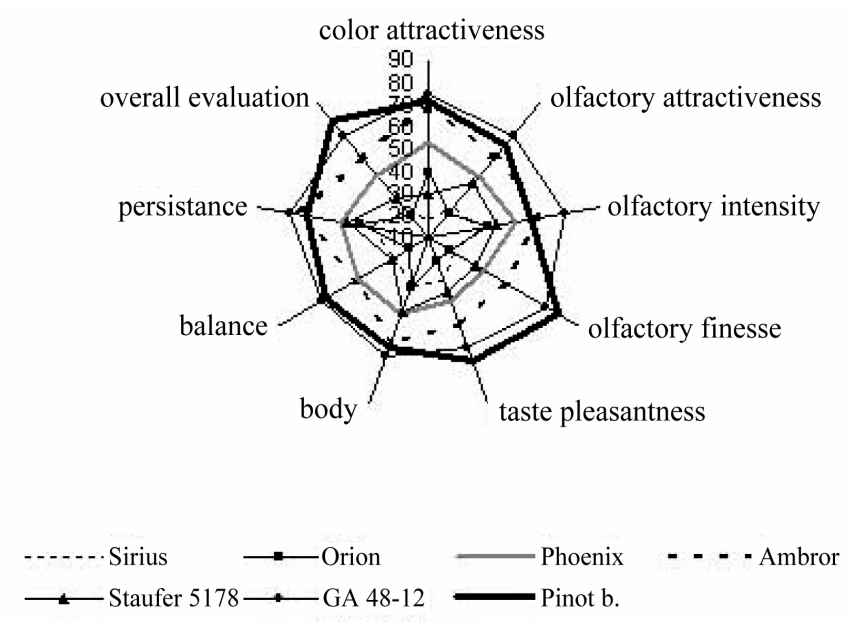

(e)

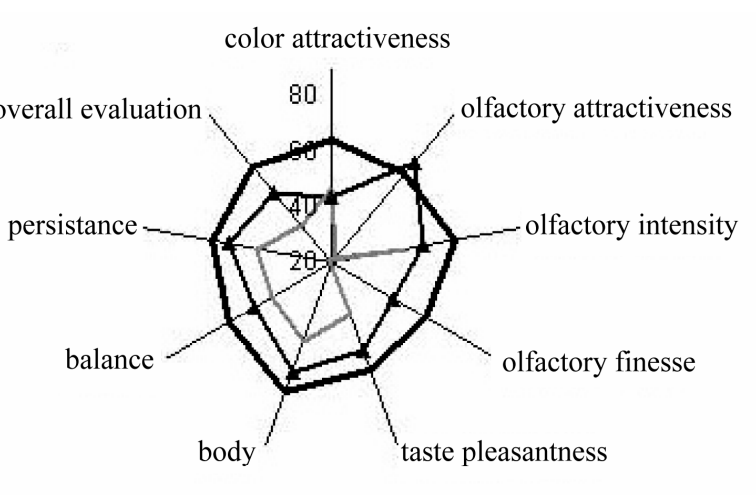

$\rightarrow$ GF 138-3 - Regent - Franconia

(b)
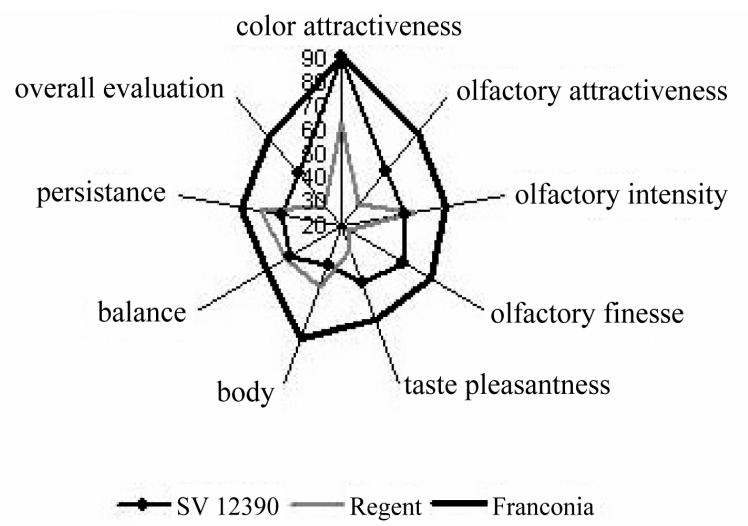

(d)

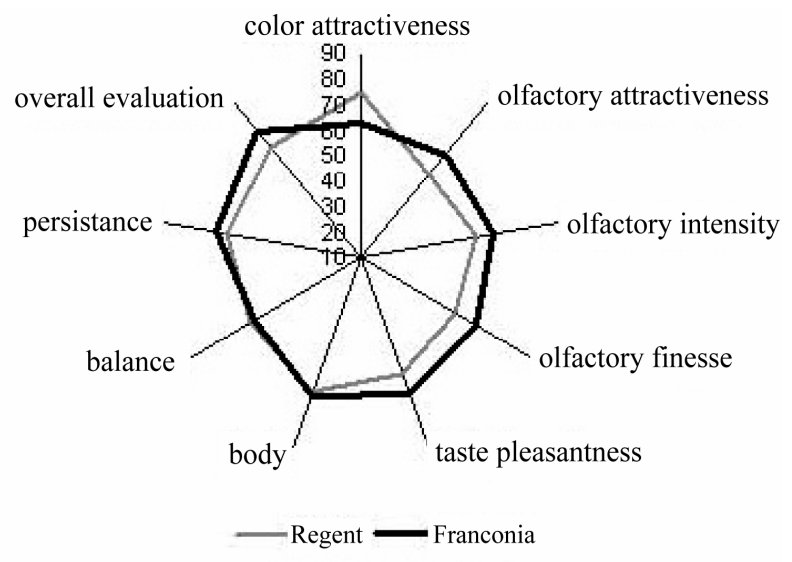

(f)

Figure 4. Aromas and flavours observed during blind wine tasting over the three-year study period. 2004 is reported in (a) and (b), 2005 in (c) and (d), 2006 in (e) and (f). The white wines are shown in (a), (c) and (e) and compared with "Pinot blanc". The red wines are shown in (b), (d) and (f) and compared with "Franconia". 
Table 6. Disease severity (expressed as \% of infection according to Townsend-Heuberger formula) at harvest in 2004 and 2005.

\begin{tabular}{|c|c|c|c|c|c|c|c|c|c|c|c|c|c|c|c|}
\hline \multirow{3}{*}{ Genotypes } & \multicolumn{6}{|c|}{2004} & \multicolumn{9}{|c|}{2005} \\
\hline & \multicolumn{4}{|c|}{ Downy mildew } & \multirow{2}{*}{$\begin{array}{c}\text { Botrytis } \\
(\%)\end{array}$} & \multirow{2}{*}{$\begin{array}{c}\text { Black rot } \\
(\%)\end{array}$} & \multicolumn{5}{|c|}{ Downy mildew } & \multirow{2}{*}{$\begin{array}{c}\text { Botrytis } \\
(\%)\end{array}$} & \multirow{2}{*}{\multicolumn{3}{|c|}{$\begin{array}{c}\text { Black rot } \\
(\%)\end{array}$}} \\
\hline & Leaf $(\%)$ & & Cluster(\%) & & & & & Leaf $(\%)$ & & Cluster (\%) & & & & & \\
\hline Phoenix & 0.2 & & 0.2 & $\mathrm{~b}$ & - & 1.0 & $\mathrm{~b}$ & 25.8 & $\mathrm{~cd}$ & 10.1 & $\mathrm{e}$ & 28.3 & $\mathrm{a}$ & - & \\
\hline Sirius & 0.0 & & 0.2 & $\mathrm{~b}$ & - & - & & 1.9 & $\mathrm{e}$ & 28.1 & $\mathrm{~cd}$ & 9.2 & $\mathrm{~b}$ & - & \\
\hline Orion & 0.0 & & 0.1 & $\mathrm{~b}$ & - & - & & 31.3 & $\mathrm{~cd}$ & 21.1 & d & 9.3 & $\mathrm{~b}$ & - & \\
\hline Ambror & 0.0 & & 0.7 & $\mathrm{~b}$ & - & - & & 29.2 & $\mathrm{~cd}$ & 47.2 & $\mathrm{~b}$ & - & & - & \\
\hline Seibel 7052 & 11.1 & $\mathrm{a}$ & 0.2 & $\mathrm{~b}$ & - & - & & 67.7 & $\mathrm{a}$ & 65.4 & a & - & & - & \\
\hline Seibel 5178 & 0.0 & & 0.0 & & - & - & & 14.1 & d & 12.2 & de & - & & - & \\
\hline GM 723-4 & 1.5 & $\mathrm{~b}$ & 0.0 & & - & - & & 53.8 & $a b$ & 17.8 & d & 4.8 & $\mathrm{~b}$ & - & \\
\hline GM 7743-8 & 0.0 & & 0.0 & & - & - & & 53.8 & $a b$ & 13.7 & de & - & & 2.6 & $\mathrm{~b}$ \\
\hline SV 39639 & 3.2 & $\mathrm{~b}$ & 0.0 & & - & - & & 25.8 & $\mathrm{~cd}$ & 2.3 & $\mathrm{f}$ & 6.6 & $\mathrm{~b}$ & - & \\
\hline SV 12390 & 0.0 & & 0.0 & & - & - & & 13.3 & d & 3.3 & $\mathrm{f}$ & 0.8 & $\mathrm{c}$ & - & \\
\hline Villard blanc & 0.1 & & 0.0 & & - & - & & 19.6 & $\mathrm{~d}$ & 1.0 & $\mathrm{f}$ & - & & 18.1 & $\mathrm{a}$ \\
\hline Staufer & 0.0 & & 6.2 & $\mathrm{a}$ & - & - & & 33.7 & $\mathrm{~cd}$ & 38.3 & $\mathrm{~cd}$ & - & & 2.0 & $\mathrm{~b}$ \\
\hline GA 48-12 & 0.0 & & 0.0 & & - & 2.0 & $\mathrm{~b}$ & 37.2 & $\mathrm{bc}$ & 17.0 & d & 10.0 & $\mathrm{~b}$ & 3.0 & $\mathrm{~b}$ \\
\hline GA $52-42$ & 0.0 & & 9.9 & a & - & 5.0 & a & 34.1 & $\mathrm{~cd}$ & 32.0 & $\mathrm{~cd}$ & - & & - & \\
\hline Saphira & 10.0 & $\mathrm{a}$ & 0.0 & & - & 2.0 & $\mathrm{~b}$ & 46.5 & $\mathrm{bc}$ & 68.7 & $\mathrm{a}$ & - & & - & \\
\hline $\mathrm{A} \times \mathrm{GM} 64-94-5$ & 0.0 & & 0.1 & $\mathrm{~b}$ & - & - & & 24.3 & $\mathrm{~cd}$ & 9.4 & $\mathrm{e}$ & - & & - & \\
\hline GF $64-170-1$ & 0.2 & & 0.2 & & - & - & & 41.1 & $\mathrm{bc}$ & 24.8 & d & - & & - & \\
\hline Regent & 0.0 & & 0.0 & & - & - & & 34.1 & $\mathrm{~cd}$ & 19.6 & d & - & & - & \\
\hline GF 138-3 & 0.0 & & 0.0 & & - & - & & 25.6 & $\mathrm{~cd}$ & 13.8 & de & 0.6 & $\mathrm{c}$ & - & \\
\hline Pinot $g$ & 12.0 & $\mathrm{a}$ & 3.0 & $a b$ & 2.0 & - & & 60.0 & a & 46.0 & $\mathrm{~b}$ & 15.0 & $a b$ & 0.0 & \\
\hline Average & 0.0 & & 0.0 & & - & - & & 33.6 & & 24.6 & & & & & \\
\hline
\end{tabular}

Note: Letters represents the significance of variability among the varieties with $\mathrm{p}<0.05$ (Duncan test).

studies concerning the cultivation and potential comercial use of hybrids in North-Eastern Italy have not been previously conducted. Although stringent European Union rules strictly limit the use of these hybrids, and advantages and drawbacks of their employment are being discussed, the results obtained from the present study indicated that breeding programmes must be pursued.

None of the hybrids under study showed high values for all agronomical characteristics tested, nor a global quality sufficient to suggest their direct application in organic viticulture. Furthermore, the high variability among the genotypes observed for agronomic, phenological and qualitative performances could provide choices suitable to different and specific oenological goals. Among the red wine cultivars, "SV 12-390" showed the lowest infection, adequate production (due to greater weight of the bunch) and a good overall wine quality. However, basing on the results obtained in the present research, our opinion is that "GF 138-3" is the most promising hybrid, showing a strong olfactory intensity, an interesting overall sensory quality and a low disease incidence. Schwab [35] recommended "Regent" for organic viticulture in "Franconia" (Germany) because the sensory analysis rated this wine at a quality higher than Pinot noir. Indeed, "GF 138-3" shares a common pedigree with "Regent", showing similar agronomic and qualitative characteristics. However, the results of the present study suggest that "GF 138-3" is better assessed in North Eastern Italy. Among the white wine varieties, our choice is "GA 48-12", showing a high quality, even when it was not fully resistant to Downy mildew. Even though, the sensory analysis rated "GA 48-12" as interesting in tasting, as reported for other hybrids [36,37], its yield must be reduced to improve the sugar content.

The further improvement of wine quality before the commercial release of hybrids is necessary. Moreover, research on agronomic practices aimed at improving the performance of single genotypes could reinforce the re- 
sults obtained through breeding programme.

\section{ACKNOWLEDGEMENTS}

Thanks are due to Dr Alessandro Zanzotto for his contribute in the disease evaluation.

\section{REFERENCES}

[1] Warner, K.D. (2007) The quality of sustainability: Agroecological partnerships and the geographic branding of California winegrapes. Journal of Rural Studies, 23, 142155. doi:10.1016/j.jrurstud.2006.09.009

[2] Broome, J. and Warner, K. (2008) Agro-environmental partnerships facilitate sustainable wine-grape production and assessment. California Agriculture, 62, 133. doi:10.3733/ca.v062n04p133

[3] Lisek, J. (2010) Yielding and healthiness of selected grape cultivars for processing in central poland. Journal of Fruit and Ornamental Plant Research, 18, 265-272.

[4] Rombough, L. (2002) The grape grower: A guide to organic viticulture. Chelsea Green Publishing, White River Junction.

[5] Fisher, K.H. (2000) The development of interspecific grapevine hybrids in Ontario, Canada. Proceedings of the 6th International Congress on Organic Viticolture, IFOAM, Basel, 25-26 August 2000, 205-208.

[6] Millardedt, A. (1885) Historie des principales varieté et espéces de la vigne. In: Mason, G., Ed., Paris.

[7] Eibach, R., Diehl, H. and Alleweldt, G. (1989) Untersuchungen zur vererbung von resistenzeigenschaften bei reben gegen oidium tuckeri, plasmopara viticola und botrytis cinerea. Vitis, 28, 209-228.

[8] Alleweldt, G., Spiegel-Roy, P. and Reisch, B.I. (1990) Genetic resources of Temperate fruit and nut crops. Acta Horticulturae, 290, 291-337.

[9] Bouquet, A. (1986) Introduction dans l'espéce vitis vinifera L. d'un caractere de résistence a oidium (uncinula necator schw. burr.) issu de l'espéce muscadinia rotundifolia (michl.) small. Vignevini, 12, 141-146.

[10] Espino, R.R.C. and Nesbitt, W.B. (1982) Inheritance of downy mildew resistence in grape (Vitis sp.). HortScience, 17, 499.

[11] Breider, H. (1964) Untersuchungen uber den einfluss des traubensaftes von hybridenreben auf den tierorganismus. Weinberg und Keller, Band, 11, 513-517.

[12] Breider, H. and Wolf, E. (1973) Negative wirkung der biostatica in resistenten reben-arthybriden auf goldhamster. Naturwissenschaften, 60, 205-206. doi:10.1007/BF00599443

[13] Becker, N.J. and Zimmermann, H. (1978) Breeding of yield varieties resistant to downy mildew. Génétique et Amélioration de la Vigne, Institut National de la Recherche Agronomique, 209-214.

[14] Mayer, G. (1989) Results of cross-breeding. Proceedings of the 5th International Symposium on Grape Breeding, St. Martin/Pfalz, 12-16 September 1989, 148.
[15] Doazan, J.P. and Kim, S.K. (1978) Recherche de génotypes résistants au mildiou dans des croisements interspecifiques. Génétique et Amélioration de la Vigne, Institut National de la Recherche Agronomique, 243-249.

[16] Kozma, P. (1986) Qualité du raisin et resistance de la vigne dans les populations hybrids interspecifiques. Vignevini, Proceedings of the 4th Symposium International Genetic Vitis, 12, 242-246.

[17] Bavaresco, L. (1990) Excursus mondiale sugli ibridi produttori di vite di terza generazione resistenti alle malattie. Vignevini, 6, 29-38.

[18] Dalmasso, G., Cosmo, I. and Dell'Olio, G. (1936) Gli ibridi produttori diretti a Conegliano-Risultati di undici anni di osservazioni. Annuario. Stazione Sperimentale di Viticoltura e di Enologia. Conegliano, 14.

[19] Cosmo, I., De Rosa, T., Calò, A. and Celotti, G. (1963) Gli ibridi produttori diretti a Conegliano dal 1952 al 1962. Annuario. Stazione Sperimentale di Viticoltura e di Enologia. Conegliano, 22.

[20] Barlass, M., Miller, R.M. and Antcliff, A.J. (1986) Development of methods for screening grapevines for resistance to infection by downy mildew. I. dual culture in vitro. American Journal of Enology and Viticulture, 37, 6166.

[21] Dalbó, M.A., Ye, G.N., Weeden, N.F., Wilcox, W.F and Reisch, B.I. (2001) Marker-assisted selection for powdery mildew resistance in grapes. Journal of the American Society for Horticultural Science, 126, 83-89.

[22] Francia, E., Tacconi, G., Crosatti, C., Barabaschi, D., Bulgarelli, D., Dall'Aglio, E. and Valè, G. (2005) Marker assisted selection in crop plants. Plant Cell, Tissue and Organ Culture, 82, 317-342. doi:10.1007/s11240-005-2387-z

[23] Charcosset, A. and Moreau, L. (2004) Use of molecular markers for the development of new cultivars and the evaluation of genetic diversity. Euphytica, 137, 81-94. doi:10.1023/B:EUPH.0000040505.65040.75

[24] Ribaut, J.M. and Hoisington, D. (1998) Marker-assisted selection: New tools and strategies. Trends in Plant Science, 3, 236-239. doi:10.1016/S1360-1385(98)01240-0

[25] Collard, B.C.Y. and Mackill, D.J. (2008) Marker-assisted selection: An approach for precision plant breeding in the twenty-first century. Philosophical Transactions of the Royal Society B, 363, 557-572. doi: $10.1098 /$ rstb.2007.2170

[26] Townsend, G.R. and Heuberger, J.W. (1943) Methods for estimating losses caused by diseases in fungicide experiments. The Plant Disease Reporter, 27, 340-343.

[27] Al-Joumayly, A. (2003) Fertlity and flower cluster position of two grape cultivars (Vitis vinifera) in south Jordan. Pakistan Journal of Biological Science, 6, 1956-1960.

[28] Fisher, K.H., Piott, B. and Barkovic, J. (1996) Adaptability of labrusca and French hybrid grape varieties to mechanical pruning and mechanical thinning. In: HenikKling, T., Wolf, T.E. and Harkness, E.M., Eds., Proceedings of the 4th International Cool Climate Enology and Viticulture Conference, Rochester, 4, 33-39.

[29] Pool, R.M., Crowe, D. and Dunst, R. (1988) The use of 
combined mechanical or minimal pruning and mechaniccal thinning in New York production systems. Proceedings of the 2nd Seminar on Mechanical Pruning of Vineyards, Treviso, February 1988, 39-46.

[30] Kaps, M.L. and Cahoon, G.A. (1989) Berry thinning and cluster thinning Influence vegetative growth, yield, fruit composition and net photosynthesis of "seyual blanco" grapes. Journal of the American Society for Horticultural Science, 114, 20-24.

[31] Morris, J.R., Main, G.L. and Oswald, O.L. (2004) Flower cluster thinning for crop control in French-American hybrid grapes. American Journal of Enology and Viticulture, 55, 423-426.

[32] Oliveira, M.T. and Sousa, T.A. (2009) Organic acids and sugars in musts of irrigated grapevines in northeast Portugal. Journal of Wine Research, 20, 1-13. doi:10.1080/09571260902978485

[33] Pavloušek, P. and Kumšta, M. (2011) Profiling of primary metabolits in grapes of interspecific grapevine varieties: Sugars and organic acids. Czech Journal of Food Sciences, 29, 361-372.

[34] Keller, M. (2010) The science of grapevines. Anatomy and Physiology, Academic Press, Burlington.

[35] Schwab, A.L., Knott, E. and Schottdorf, W. (2000) Results from new fungus-tolerant grapevine varieties for organic viticulture. Canada. Proceeding of the 6th International Congress on Organic Viticolture, 25-26 August 2000, 225-227.

[36] Hummel, A.K. and Ferree, D.C. (1998) Interaction of crop level and fruit cluster exposure on seyval blanc fruit composition. Journal of the American Society for Horticultural Science, 123, 755-761.

[37] Mabe, C.L. (1983) Effects of shoot thinning, cluster thinning, training system and maturity on yield and quality of six cultivars of French hybrid wine grapes. University of Arkansas, Fayetteville. 